УДК 371(091)(520)

DOI 10.11603/me.2414-5998.2020.2.11143

N. O. Fedchyshyn ${ }^{1}$

ORCID https://orcid.org/0000-0002-0909-4424

ResearcherID Q-5422-2016

Scopus Author ID 57202833382

Edvard Protner ${ }^{2}$

Scopus Author ID 55749809900

${ }^{1}$ I. Horbachevsky Ternopil National Medical University

${ }^{2}$ University of Maribor, Slovenia

\title{
HERBART AND HERBARTIANISM IN EUROPEAN PEDAGOGY: HISTORY AND MODERNITY
}

\author{
Н. О. Федчишин ${ }^{1}$ Едвард Протнер ${ }^{2}$ \\ ${ }^{1}$ Тернопільський національний медичний університет \\ імені І. Я. Горбачевського МОЗ України \\ 2Маріборський університет, Словенія

\section{ГЕРБАРТ І ГЕРБАРТІАНСТВО В ЄВРОПЕЙСЬКІЙ ПЕДАГОГІЦІ: ІСТОРІЯ Й СУЧАСНІСТЬ}

\begin{abstract}
The proposed article offers an assessment of J.-F. Herbart and Herbartians in the history of pedagogy of Germany, prerevolutionary Russia, and Ukraine; the influence of the doctrine of J.-F. Herbart and Herbartians on the development of pedagogical science; borrowing ideas of these representatives in school education, namely the processes of formation, changes in directions, ideas, principles and tasks of the educational process; structural and substantive features of Herbartian pedagogy are revealed. It has been outlined the ways of popularizing Herbartianism in European countries and the significance of the theoretical heritage of Herbartians in the modern history of pedagogy.
\end{abstract}

Key words: Herbartianism; J.-F. Herbart; pedagogical views; curriculum; theory and practice.

Анотація. У статті запропоновано оцінку діяльності Й.-Ф. Гербарта і гербартіанців в історії педагогіки Німеччини та дореволюційної Росії, а, відтак, й України; окреслено вплив вчення Й.-Ф. Гербарта і гербартіанців на розвиток педагогічної науки; досліджено запозичення ідей цих представників у шкільній освіті, а саме процеси формування, зміни в напрямах, ідеях, принципах і завданнях навчально-виховного процесу; розкрито структурні та змістові особливості гербартіанської педагогіки; окреслено шляхи популяризації гербартіанства в європейських країнах та значення теоретичної спадщини гербартіанців у сучасній історії педагогіки.

Ключові слова: гербартіанство; Й.-Ф. Гербарт; педагогічні погляди; навчальний план; теорія і практика.

Introduction. The subject of current controversy among politicians, scholars, practitioners is the problem of the entry of the national educational system into the multicultural space of the European Community. The process of integration, as one of the priority directions of the state policy in the field of education, requires the society to coordinate the national pedagogical experience with the progressive experience of other countries in this field, which actualizes the multifaceted study of problems of foreign pedagogy.

Nowadays, the evaluation of J.-F. Herbart's works still remains controversial. The reason for this is the

(C) N. O. Fedchyshyn, Edvard Protner versatility of his personality. He is a teacher, practitioner, organizer, prognosticator, who not only surpassed the achievements of his contemporaries, but also tried to realize his own concept, which was unusual for the era. Accordingly, his legacy was presented in a set of ideas, without their proper justification and explanation of the mechanisms of embodiment, "canonized" after the scientist's death as a permanent and dogmatic doctrine. The influence of the ideas of pedagogical trends of the West countries on the content, methods and forms of organization of educational process in schools of Ukraine caused historical and pedagogical explorations, critical articles on the given problem. The 
pedagogical concept of the Herbartians ("the darkest and most forgotten pages of the history of pedagogy of the nineteenth century") is rather interesting as it reflects the need for its systematic study and holistic scientific consideration $[11,16]$.

Since the 90s of the twentieth century we saw the renewed interest in the pedagogy of J.-F. Herbart and Herbartians, first of all, in Germany. The conferences in Oldenburg (1991, 1994, 1996, 2001, 2003) were rather significant. In 1997 a similar congress took place in Jena (the center of German Herbartianism through the mediation of K.-F. Stoy and W. Rain), later in 2005 - St. Niklaas (Belgium), 2007 - Halle (Germany), 2009-Eichstaett-Ingolstadt (Switzerland), 2011 - Warsaw (Poland), 2013 - Essen (Germany), 2015. - Karlsruhe (Germany), 2017 - Paris (France), 2019 - Yena (Germany). On the basis of the above we can conclude that the scientific school of J.-F. Herbart returns, enriches pedagogical science, provokes regular discussions, which are the key to development.

The aim - to investigate the perception of J.-F. Herbart and Herbartianism in the European history of pedagogy, the influence of their teaching on the development of pedagogical science, on the structural and substantive features of pedagogy.

Theoretical framework. Discovering the panorama of the perception of Johann Friedrich Herbert's pedagogical theory and practice in various countries is extremely important for implementation. The results of the study show that, on the one hand, it is impossible to ignore his pedagogical ideas, and on the other hand, they have to state that the views of the German teacher have long been unjustified criticism.

Despite high praise of pedagogical achievements of J.-F. Herbart in Russia, his works have been critically analyzed in Germany. In 1865 T. Lange published "Fundamentals of Mathematical Psychology", where he tried to point out the basic errors of J.-F. Herbart and his followers. At that time, other articles were published in which the views and doctrine of J.-F. Herbart were suggested, e.g. R. Zimmermann - "The Periods of Herbart's Philosophical Intellect” ("Perioden in Herbarts philosophischen Geistesgang”) (1877), J. Capesius “The Metaphysics of Herbart in the History of Development and from a Historical Point of View" ("Die Methaphisyk Herbarts in ihrer Entwicklungsgeschichte und ihrer historischen Stellung”) (1878), J. Kaftan “Oblivion and Being in Relation to Each Other; study of Herbert's critique" ("Sollen und Sein in ihrem Verhältnis zueinander; eine Studie zur Kritik Herbarts”) (1872) [14, 19].
V. Asmus prepared a number of analytical works and publications by J.-F. This is why Herbart became known in the scientific community. In particular, $\mathrm{V}$. Asmus, pointed to the importance of the pedagogical views of J.-F. Herbart for his contemporaries, among the most important considered the following issues: the teachings of J.-F. Herbart on pedagogical prerequisites for successful learning and upbringing, confirmed in detail by G. Roth in pedagogical anthropology; the doctrine of J.-F. Herbart on diversity of interest; education as "experience and communication"; education and authority (J.-F. Herbart came to the understanding that from childhood a student should get used to restrictions); the problem of education and society; education of independence; education through training; elementary education (J.-F. Herbart cited specific examples in "Pestalozzi's Ideas of Visual Perception”); distribution of training; education through a range of thoughts that go through degrees: the development of versatility of interest, the aesthetic image $[8,9]$.

After the Second World War, thanks to the teacher $\mathrm{V}$. Asmus, the original pedagogical teaching of J.-F. Herbart during 1968-1970 in Heidelberg it was published a biography of J.-F. Herbart, which, given the accuracy of the number of sources and facts presented, could not be surpassed.

In the article "Herbart as a school reformer" (1941) $K$. Zailer argued with the reproaches of intellectualism, mechanics, morality and individuality. He cited several quotations where J.-F. Herbart warned about some of the goals of the school reform movement, such as the development of efforts, the drive for inner activity, the principle of a work school (G. Gaudig), guiding ideas of the art of education. K. Sailer added that "the reform process of the German school is contrary to the provisions of J.-F. Herbart and this is the irony of the situation" [18]. A similar example of the evaluation of the pedagogical works of J.-F. Herbart may be a study of H. Caselman's “Unsystematic Herbart”. The scientist pointed to the views of J.-F. Herbart about the "pedagogical tact" where he saw the connection of theory with practice. "Actually, a certain tact, quick assessment and decisions should act not inertly, and not as a theory that must be completed", he explained [10].

In the nineteenth century the perception of the school as "teacher's school, school of books, school of educational material" was changed. J.-F. Herbart was the complete opposite of G. Kerschensteiner's vocational school. It should be noted that the teacher 
and reformer P. Petersen (1884-1952) respected the views of J.-F. Herbart about experience and communication as the "foundation of spiritual life" is the most progressive in the field of study. P. Petersen noted that J.-F. Herbart in his main work, "General Pedagogy Derived from the Purpose of Education", which was later called "General Pedagogy” (1806), pointed out the inadequacy and need for training, which is not at all a complement to experience and communication [15].

Despite the critical analysis of certain J.-F. Herbart's conceptual provisions (V. Drobisch, J. Capesius, J. Kaftan, T. Lange, O. Frick, R. Zimmermann), however, German researchers emphasized the connection between the theoretical foundations of J.-F. Herbart with the like in the inheritance of distinguished teachers of Europe - J.-A. Komenskyy and J.-G. Pestalozzi. The most crucial conclusions are supposed to be the ones of the scientists from the German School of History of Pedagogy (D. Benner, J. Blass, E. Geissler, G.-M. Elzer, B. Shwenk) who proved the pedagogical ideas of J.-F. Herbart. Therefore, the new return to the teacher's and Herbartians assets is marked by the end of World War II and the post-war reformation of education, the need for a new study of its fundamentally important principles (E. Anhalt, V. Asmus, V. Bretsinka, R. Coriand, A. Nemeth, G. Nol, E. Protner, A. Tshavdarova, B. Vince, K. Zayler). A great interest in the work of J.-F. Herbart and his pedagogical concept was shown in the late nineteenth century. This is evidenced by the fact that a large number of publications appeared during this period [7]. In 1887 and 1900 the Russian translation of the Didactic Catechism was published by the follower of J.-F. Herbart's pedagogical views O. Frick. His work outlined ways for beginning educators on the psychological process of learning and teaching for the purpose of education. The scientist, aware of the discrepancy between the provisions of his theory and their interpretations, in every possible way tried to eliminate inaccuracies, and thus prevented the error of interpretation. In general, the style and presentation of Herbert's works implied a deep awareness of readers with disciplines related to pedagogy, first of all, psychology and philosophy. However, researchers of J.-F. Herbart tried to interpret and comment on his pedagogical heritage independently. Accordingly, the views of the scientist lost their authorial content. Such inaccuracies predetermined criticisms of readers, although they did not relate to the conceptual provisions of the teacher, because they led to sometimes unsuccessful interpretations of his works [12].

Despite the approving assessment of certain conceptual provisions by J.-F. Herbart, Soviet scientists (B. Komarovskyy, N. Krupskaya) brought a number of critical remarks to his didactic legacy. First, it was pointed out that the pedagogical process as a whole was covered by J.-F. Herbert is wrong because it was abstracted from the teaching material and psychology of the students. Second, the teachings of J.-F. Herbart about educational teaching and diversity of interest, which was based on metaphysics and religion, was a "reactionary element" of his pedagogy, and the content embedded in it is metaphysical and unscientific [2]. Third, it is concluded that one should not agree with the views of J.-F. Herbart on the role of the student and teacher in the pedagogical process, since the latter did not recognize the independent role and independent thinking of the student, putting the guidance of the student's thinking on the teacher [2].

J.-F. Herbert defined the development of students' minds in shaping their ability to analyze, synthesize, and think logically. Thus, he referred to the methods descriptive (pictorial), analytical and synthetic. The scientist did not aim to determine the advantages of one method over another, constantly emphasizing the expediency of using in conjunction with them and a considerable number of different techniques according to the circumstances of the real pedagogical process. He argued that in the teaching methods offered, the teacher should properly reflect the essence of the process itself, directing its participants to collaborative activities. Accordingly, only this approach can promote their development, encourage them to work, and shape their personality comprehensively. In general, this will provide an interest in learning, which should be visual, inseparable from reality, "magnifying" and exciting. Synthesizing different teaching tools, he simultaneously combined elementary methods of J.-G. Pestalozzi with the conversation method of I. Bazedov. Learning methods are permanently modified according to the variability of the purpose and content of the learning. Considering the task of learning to produce accurate ideas, J.-F. Herbart preferred to rule strict regulations in developing the material. The latter is reflected even in the techniques of presentation of the material, they are characterized by a large number of titles, diagrams, tables, dryness and efficiency of style. He emphasized that all three teaching methods 
should properly show, connect, teach, justify, compel to work, develop personality and arouse interest [12].

Considering the relationship between education and upbringing J.-F. Herbart introduced the term "educational training” ("Erziehender Unterricht”) (1806), and noted that teaching is not always pedagogical, and clarified that it is only about the educational, the core of which is knowledge. J.-F. Herbart's interpretation of learning through the prism of the education was a result of the critical analysis of the history of pedagogical thought [16]. Therefore, he used the term "educational training" in line with pedagogical traditions. Herbart's interpretation was preceded by the scientific and historical substantiation of Ya. A. Komenskyy and J.-G. Pestalozzi. The conceptual basis of J.-F. Herbart was reduced to the inadmissibility of separating education from education. In general, it was the only complex and complicated process that lead to educational training. This is how J.-F. Herbart justified the current didactic principle of educational training, which subsequently became widespread in Germany, France, Russia, and Poland [13].

In modern conditions it is necessary to think over the influence and place of religious teaching and upbringing, which in the pedagogy of J.-F. Herbart took the lead. The Christian religion was and remains an important element of the European peoples' lives, so the state cannot ignore the influence of the Church. The scholar considered the Church and the school equal institutions of the state system.

In Russia, the outstanding teacher of the time P. Kapterev thoroughly analyzed the development of pedagogical ideas in Germany, the practice of Herbartian educators and substantiated their influence on the development of national pedagogy in the late nineteenth and early twentieth centuries. In his work "Modern Pedagogical Currents" (1913), he noted that Germany was the "cradle of all major pedagogical movements and currents", which were later perceived in other countries [1]. The scientist was joined by well-known teachers of that time such as Guy in Lausanne, Credoro in Rome, Sandler and Findlay in England, De Garmo in America. The teacher pointed out on the fact that the ideas, originated and emerged in Germany, were much bolder and more widely implemented in school practice, initially in different European countries, and much later influenced the life of the German school (philanthropism in the new schools in England, France and America, experimental pedagogy). It should be emphasized that at that time (end of XIX - beginning of XX century) Germany took "the first place in the world in the number of scientific pedagogical journals" [2]. It is also worth noting that a much larger number of periodicals were published in German than in other European languages.

According to O. Muzychenko and P. Kapterev, the Herbartian trend in Germany was the most widespread and stable. The trends of the Herbartians were inherent: a developed system of concepts, closeness to the student and teacher, immersion in the problems of didactics, which was the impetus for popularity and imitation at that time in the civilized countries of Europe [1, 4, 5]. Scientists focus on pedagogical journals and associations that theoretically studied J.-F. Herbart's pedagogy. Therefore, it should be added that the ideas of the latter have found interest in teachers-researchers of the departments of Jena, Meiningen, Temaru, Weimer, Eisenach.

The followers and supporters of the German scientist's doctrine successfully implemented his provisions regarding the curriculum, concentration in teaching, methodical study of new material, etc. These and other ideas were analyzed by Herbartians and found particular support in official documents in the Thuringian schools. Herbartianism was the mainstay of the pedagogical seminar and the Department of Pedagogy at the University of Jena, headed by Professor W. Rain. In his work "Pedagogy in systematic teaching" ("Pagagik in systematischer Darstellung”), he thoroughly elaborated and clearly stated his own understanding of the pedagogy of his teacher. In his opinion, it should be based on broad philosophical views, not on common practices and vague formulas [17].

From the Marxist point of view, the views of the Herbartians were analyzed by N. Krupskaya, who believed that the development of progressive thought was constantly in constant struggle with reactionary currents. She agreed that Herbartianism was in the nineteenth century. The most widespread and influential pedagogical system, however, only met the interests of the ruling class. N. Krupskaya criticized the school, established on the basis of Herbartian principles, the understanding of moral education as the education of personal morality, which relies on constant ideas, eternal and "superhuman", antisocial nature of the system. She expressed her dissatisfaction with the cramming at this school, the separation of knowledge, and the inhibition of the 
student's individuality, which contributes to automatic obedience [6].

In the articles "The Spirit of Time in the German People’s School”, “On School Self-Government”, “A Positive Method of Teaching”, N. Krupskaya sharply criticized the bourgeois society for encouraging the teacher to train students [6]. Her assessment of Herbartianism was "confirmed" later by studies by Soviet and German (GDR) educators. Obviously, this circumstance can explain the increased interest of Soviet pedagogy in the period of its becoming practical activity of "new schools" abroad. During this period systematic researches of problems of theoretical bases, content, forms of organization of educational process are conducted.

The works of O. Muzychenko "Philosophical and pedagogical thought and school practice in modern Germany”, "Johann Friedrich Herbert and his school” were of particular interest among scholars and teachers. He explained the reasons for spreading the teachings of the Herbartians as being "meeting the dogmatic need of the national teacher" $[3,5]$. O. Muzychenko advised to acknowledge the positive aspects of Herbartian pedagogy and to draw attention to the practical school at Jena University, other practitioners of the city educational institutions of Jena, where a free, modernized understanding of the great classic reigns. This form of teaching was called "developmental learning" "Entwickelnder Unterricht" (it wasn't a term of J.-F. Herbart) i.e. a method of developing educational material. Such doctrine is based not only on visual ideas and experience, but also on the student's own ideas when he sees and feels the internal and logical connections between the facts [4]. Thus, A. Muzychenko came to the conclusion that the teacher's task is to teach the student to observe, to study, to analyze, to understand the world and the environment, to be able to make an assessment and to make certain summaries.

O. Muzychenko spent some time in a pedagogical university and was able to observe the educational and learning process of the elite at school, which was founded at the time by the students and supporters of the teachings of J.-F. Herbart in Jena. In particular, he noted that the ideas of J.-F. Herbart, some aspects of his pedagogical concept, which found a positive development in the work of his followers, were later distorted: individualism when unwilling to pay attention to the problems of life of public school, mass education; an attempt to neglect the upbringing of freedom. The results of O. Muzychenko's research in the report "Special Occupation in Pedagogy in Foreign
Travel (1906-1908)" confirmed that the paradigm of Herbartianism influenced in the XIX-XX centuries not only to European schools, but also to the development of pedagogical ideas in Russia through the mediation of M. Pyrohov and K. Ushynskyy [4].

In the early twentieth century, Herbartianism was introduced into textbooks and manuals on the history of pedagogy (M. Demkov (1912), S. Levitin (1918), A. Levitskiy (1912), A. Nechaiev (1911), and F. Paulsen (1908), M. Rubinstein (1916), A. Muzychenko (1917), A. Selikhanovich (1917), L. Sinitsky (1905), P. Sokolov (1913), O. Frick (1900); foreign historians published the pedagogical studies of the German teacher's school (P. Bart (1913), P. Monroe (1917), H. Ufer (1898), T. Ziller (1911)) in Russian. The study of the above scientists brings together the recognition of J.-F. Herbart as a "founder of scientific pedagogy".

Professor B. Komarovskyy in his article "Towards a History of the Herbartian Direction in Pedagogy" (1940) made a number of positive comments on the work of the Herbartians and their teacher. In particular, he emphasized the development of the theory of the lesson, its principles are planarity, disunity, consistency, continuity, systematization and generalization of the material, management and application. B. Komarovskyy noted that German educators rightly criticized pedo-centrism and demanded that the teacher be given a leading role in the pedagogical process [2].

Conclusions and Prospects for Research. Therefore, the textbooks and manuals of the mid-nineteenth and twentieth centuries reflected the logical link between science and practice, which was a pivotal element in J.-F. Herbart's pedagogical system. Diversity of assessments, discussions on the significance of J.-F. Herbart are evidences of the importance of his pedagogical system.

In pedagogy, the assessment of Herbartianism was quite controversial. If the researchers of pedagogy of the nineteenth century understood the value of views J.- F. Herbart and his school, in the early twentieth century the first attempts of their sharp criticism arose. By the 30-ies of the twentieth century national science completely abandoned the pedagogical heritage of the past, silenced and distorted the content of those new ideas and approaches to education, which were developed in the late nineteenth - early twentieth century in Western Europe, the pedagogy of Germany was no exception. Our further research will address the impact of Herbart and his school on teacher training in Austro-Hungarian Galicia. 


\section{Materials of International Scientific and Practical Conference \\ “PROFESSIONAL AND COMMUNICATION CULTURE OF THE FUTURE DOCTOR: LINGUISTIC, PEDAGOGICAL AND PHILOSOPHICAL ASPECTS”}

\section{List of literature}

1. Каптерев П. Ф. Дидактические очерки / П. Ф. Каптерев. - М. : Виктория, 1915. - 423 с.

2. Комаровский Б. К истории гербартианского направления в педагогике / Б. Комаровский // Советская педагогика. - 1940. - № 2. - С. 17-29.

3. Музыченко А. Ф. Иоганн Фридрих Гербарт и его школа / А. Ф. Музыченко // Очерки по истории педагогических учений. - М. : Польза, 1911. - С. 46-169.

4. Музыченко А. Ф. Отчет о специальных занятиях педагогикой в заграничной командировке (19061908 гг.) / А. Ф. Музыченко. - Нежин, 1908. - 66 с.

5. Музыченко А. Ф. Философско-педагогическая мысль и школьная практика в современной Германии / А. Ф. Музыченко // Известия историко-филологического института князя Безбородько. Т. XXIV. - Нежин, 1909. - 34 с.

6. Павлюк С. Розвиток освітньо-наукового комплексу Німеччини в умовах європейської інтеграції / С. Павлюк // Вища школа: науково-практичне видання. 2011. - № 5-6. - C. 61-70.

7. Anhalt E. Herbarts pädagogische Problemstellung aus heutiger Sicht / E. Anhalt, J. F. Bildsamkeit // Zum aktuellen Erbe Herbarts. Ein Klassiker der Pädagogik nach der Jahrtausendwende. - Oldenburg, 2004. - S. 99-138.

8. Asmus W. Die Autonomie der Pädagogik Herbarts / W. Asmus // Zeitschrift für Pädagogik, Jahrgang 21 - Heft 3 Juni 1975. - Weinheim : Beltz Verlag, 1975. - S. 419-439.

9. Asmus W. Herbart in seiner und in unserer Zeit / Walter Asmus Autor/in Asmus Walter Ausgabe 1. Aufl. Ort/Verlag Essen: Neue Deutsche Schule Verlagsges. 1972. - 42 S.

10. Caselmann Ch. Der unsystematische Herbart / Ch. Caselmann. - Heidelberg, Verlag Quelle \& Meyer, 1962. - 91 S.

\section{References}

1. Kapterev, P. (1915). Didakticheskiye ocherky [Didactic essays]. Moscow: Viktoriya [in Russian].

2. Komarovskyy, B. (1940). K istorii gerbartianskogo napravleniya $\mathrm{v}$ pedagogike [On the history of the Herbarian direction in pedagogy]. Sovetskaya pedagogika - Soviet Pedagogy, 2, 17-29 [in Russian].

3. Muzychenko, A.F. (1911). Yogann Frydryh Gerbart i yego shkola [Johann Friedrich Herbart and his school]. Ocherky po istoriiy pedagogycheskykh ucheniy. Moscow: Polza [in Russian].

4. Muzychenko, A.F. (1908). Otchet o spetsialnykh zanyatiyakh pedagogikoy $v$ zagranichnoy komandirovke (1906-1908 gg.) [Report on special classes in pedagogy on a business trip abroad (1906-1908)]. Nezhyn [in Russian].

5. Muzychenko, A.F. (1909). Filosofsko-pedagogicheskaya mysl i shkolnaya praktika v sovremennoy Germanii [Philosophical and pedagogical ideas and school practice in modern Germany]. Izvestiya istoriko-filologicheskogo instituta kniazya Bezborodko. T. XXIV. Nezhyn [in Russian].
11. Coriand R. Der Herbartianismus - die vergessene Wissenschaftsgeschichte / R. Coriand. - Klinkhardt : Bad Heilbrunn, 2003. - 310 S.

12. Fedchyshyn N. Johann Friedrich Herbart i pedagogika herbartowska w czasah globalizaciji Europy / N. Fedchyshyn // Wybrane zagadnienia jak ościks ztałceniai dokształcania. - Dąbrowa Górnicza. 2014. - S. 93-102.

13. Fedchyshyn N. The Educational Activity in Galicia at the Beginning the $20^{\text {th }}$ of the Century: Historic-Pedagogical Analysis and Perspectives / N. Fedchyshyn, T. Magsumov // Східноєвропейський історичний журнал. - 2019. № 10. - С. 66-73.

14. Lange M. G. Totalitäre Erziehung. Das Erziehungssystem der Sowjetzone Deutschlands / M. G. Lange. - Frankfurt : Verlag der Frankfurter Hefte, 1954. - 432 S.

15. Petersen P. Führungslehre des Unterrichts / P. Petersen. - Braunschweig, 2. Auflage 1950. - 93 S.

16. Protner E. Die Formalstufen und die "Verdammung" des Herbartianismus am Beispiel Sloweniens. In: E. Adam, G. Grimm (Hg.): Die Pädagogik des Herbartianismus in der Österreichisch-Ungarischen Monarchie. Wien : LIT-Verlag, 2009. S. 113-130.

17. Rein W. Pädagogik in systematischer Darstellung / W. Rein. - 3. Bd. C.: Methodologie. Die Lehre von den Mitteln der Erziehung.2. Aufl. - Beyer \&Söhne, Langensalza, 1912. - $361 \mathrm{~S}$.

18. Seiler H.Herbart's Grundlegung der wissenschaftlichen Pädagogik / H. Seiler. - Aachen, 1966. - 319 S.

19. Zimmermann W. Lehrplantheorie und Schulreform / W. Zimmermann // Bildung und Erziehung. - Düsseldorf : Pädagogischer Verlag Schwann, 1971, 24. Jhg., 1.Heft. S. 81-96.

6. Pavliuk, S. (2011). Rozvytok osvitno-naukovoho kompleksu Nimechchyny $v$ umovakh yevropeiskoi intehratsii [Development of the educational and scientific complex of Germany in the conditions of European integration]. Vyshcha shkola: naukovo-praktychne vydannia [in Ukrainian].

7. Anhalt, E. (2004). Bildsamkeit. J.F. Herbarts pädagogische Problemstellung aus heutiger Sicht. In: Zum aktuellen Erbe Herbarts. Ein Klassiker der Pädagogik nach der Jahrtausendwende. Oldenburg.

8. Asmus, W. (1975). Die Autonomie der Pädagogik Herbarts. Zeitschrift für Pädagogik. Jahrgang 21 - Heft 3 - Juni 1975. Weinheim: Beltz Verlag.

9. Asmus, W. (1972). Herbart in seiner und in unserer Zeit. In: Asmus Walter Ausgabe 1. Aufl. Ort/Verlag Essen: Neue Deutsche Schule Verlagsges.

10. Caselmann, Ch. (1962). Der unsystematische Herbart. Heidelberg, Verlag Quelle \& Meyer. 


\section{Materials of International Scientific and Practical Conference \\ "PROFESSIONAL AND COMMUNICATION CULTURE OF THE FUTURE DOCTOR: LINGUISTIC, PEDAGOGICAL AND PHILOSOPHICAL ASPECTS”}

11. Coriand, R. (2003). Der Herbartianismus - die vergessene Wissenschaftsgeschichte. Rotraud Coriand. Klinkhardt: Bad Heilbrunn.

12. Fedchyshyn, N. (2014). Johann Friedrich Herbart i pedagogika herbartowska w czasah globalizaciji Europy. In: Wybrane zagadnienia jak ościks ztałceniai dokształcania. Dąbrowa Górnicza.

13. Fedchyshyn, N., \& Magsumov, T. (2019). The Educational Activity in Galicia at the Beginning the $20^{\text {th }}$ of the Century: Historic-Pedagogical Analysis and Perspectives. Skhidnoyevropeiskyi istorychnyi zhurnal - East European Historical Journal, 10, 66-73.

14. Lange, M.G. (1954). Totalitäre Erziehung. Das Erziehungssystem der Sowjetzone Deutschlands. Frankfurt: Verlag der Frankfurter Hefte.
15. Petersen, P. (1950). Führungslehre des Unterrichts. Braunschweig, 2. Auflage.

16. Protner, E. (2009). Die Formalstufen und die „Verdammung“ des Herbartianismus am Beispiel Sloweniens. In: E. Adam, G. Grimm (Hg.): Die Pädagogik des Herbartianismus in der Österreichisch-Ungarischen Monarchie. Wien: LIT-Verlag.

17. Rein, W. (1912). Pädagogik in systematischer Darstellung. 3. Bd. C.: Methodologie. Die Lehre von den Mitteln der Erziehung. 2. Aufl. Beyer \&Söhne, Langensalza.

18. Seiler, H. (1966). Herbart's Grundlegung der wissenschaftlichen Pädagogik. Aachen.

19. Zimmermann, W. (1971). Lehrplantheorie und Schulreform. Bildung und Erziehung. Düsseldorf: Pädagogischer Verlag Schwann, 24. Jhg., 1.Heft.

E-mail address for correspondence: fedushunno@tdmu.edu.ua 